\title{
U.S. Regional Business Cycles and the Natural Rate of Unemployment
}

\author{
Howard J. Wall and Gylfi Zoëga
}

(

$\mathrm{n}$ the late 1960s, Milton Friedman and Edmund Phelps convinced the economics profession that there was no long-run trade-off between inflation and unemployment. A policy that tries to maintain the unemployment rate below a certain threshold (dubbed the natural rate of unemployment by Friedman) would lead to rising inflation, while trying to maintain it above the threshold would lead to ever-declining rates of inflation. The proposition of long-run neutrality of inflation and money growth soon gained wide acceptance, and work in this area has focused on making the natural rate of unemployment fully endogenous in generalequilibrium models (Pissarides, 2000; Layard, Nickell, and Jackman, 1991; and Phelps, 1994). This theory can be used to show how a variety of macroeconomic shocks - such as the rate of technical progress, real interest rates, and oil pricesaffect the natural rate and social welfare.

Inflation-targeting central banks often monitor employment and wage changes in the hope of preventing wage inflation in the labor market from generating general price inflation. ${ }^{1}$ The use of the notion of an equilibrium level of unemployment that is independent of current and past monetary variables has made the estimation of the natural rate important. This practice relies on representativeagent type models - the ones used to provide microeconomic foundations for the inflation/ unemployment relationship - to assess the state of the economy using aggregate data. A central banker may then use data on aggregate employment, unemployment, and average wage inflation across all sectors of the economy to assess the position of the economy in relation to an estimate of the natural

\footnotetext{
1 Such considerations have led to the appointment of a labor economist, Steve Nickell, to Britain's Monetary Policy Committee.
}

rate of unemployment. Most often, the estimate is the implied natural rate in an econometric model of the aggregate Phillips curve.

The objective of this article is to show that the sole reliance on aggregate data may lead to incorrect inferences about the natural rate of unemployment. We show how regional business cycles might affect aggregate wage inflation and how attention to regional labor market trends can be useful for understanding the aggregate labor market. Moreover, we show how the natural rate of unemployment may depend directly on the dispersion of economic activity across regions.

Our regional approach is in some ways parallel to the sectoral approach of Lilien (1982), Abraham and Katz (1986), and Brainard and Cutler (1993). Lilien (1982) found that a measure of sector-specific disturbances accounted for a significant portion of the variation in aggregate employment: When an industry sheds redundant labor in less time than it takes for the affected workers to find employment elsewhere, unemployment rises when the pace of sectoral reallocation of labor (and capital) increases. Abraham and Katz (1986) pointed out that Lilien's estimates might exaggerate the role of sectoral disturbances by failing to take into account differences in the sensitivity of different industries to macroeconomic shocks. Brainard and Cutler (1993) developed a data series to measure the intensity of reallocation shocks. They constructed a time series of the variance of sectoral stock market excess returns and found that they had a modest - though statistically significant-role in explaining aggregate employment fluctuations.

Our paper follows recent work illustrating the significant regional differences in economic conditions, business cycle dynamics, and reactions to monetary policy. Overman and Puga (2002) demonstrate the increased polarization of unemployment

Howard J. Wall is a research officer at the Federal Reserve Bank of St. Louis. Gylfi Zoëga is a professor of economics at the University of Iceland; a reader of economics at Birkbeck College, University of London; and an academic adviser to the Central Bank of Iceland. The authors thank seminar participants at the Central Bank of Iceland, the Federal Reserve Bank of St. Louis, and the Institute for Monetary and Economic Studies of the Bank of Japan for their comments and suggestions. The views expressed are those of the authors and do not necessarily represent official positions of the Central Bank of Iceland, the Federal Reserve Bank of St. Louis, or the Federal Reserve System.

Federal Reserve Bank of St. Louis Review, January/February 2004, 86(1), pp. 23-31.

(C) 2004, The Federal Reserve Bank of St. Louis. 


\section{Figure 1}

\section{U.S. Unemployment and Its Coefficient of Variation Across States}

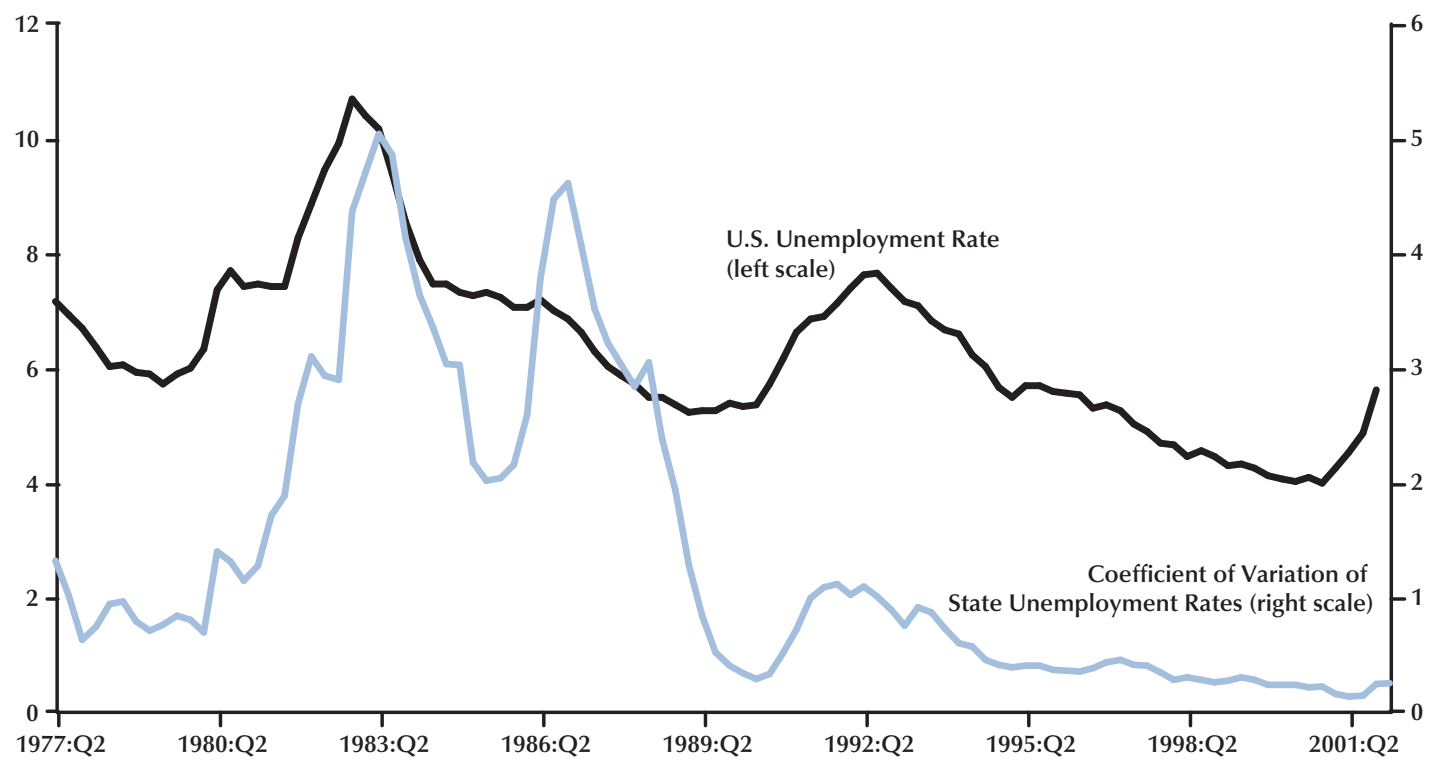

within Europe, where unemployment increasingly appears in regional clusters that cross national borders. Crone (1998/1999) groups the U.S. states into regions based on common cyclical behavior, while Carlino and Sill (2001) find considerable state differences in the volatility of regional cycles. Owyang, Piger, and Wall (2003) identify distinct state-level recession/expansion phases, finding a great deal of business cycle discord among the states and between individual states and the country as a whole. They also find significant cross-state differences in the depths of recessions and the speed of expansions. Recent research has also found that states and regions respond differently to monetary policy (Carlino and DeFina, 1998; Fratantoni and Schuh, 2003; and Owyang and Wall, 2003).

It follows from these studies that the national economy of the United States is a composite of significantly diverse but interrelated regional economies. In this paper, we show how the diversity in regional labor market conditions can be used to enrich policymakers' understanding of the aggregate economy. In the next two sections, we briefly lay out a state-level view of recent U.S. labor market trends and then describe how differences in regional business cycles can lead to changes in aggregate wage inflation. In the final section, we test for the underlying conditions for this to occur and demonstrate how region-level data can be used to estimate the aggregate natural rate of unemployment in the United States.

\section{A STATE-LEVEL VIEW OF U.S. UNEMPLOYMENT}

This article relies on two suppositions about the dispersion of regional labor market conditions: (i) that the dispersion is related to aggregate labor market conditions and (ii) that the dispersion changes over time. Both suppositions are supported by Figure 1, which illustrates that the movements in the aggregate unemployment rate over the past 25 years have largely been in synch with changes in the dispersion of state unemployment rates (as measured by the cross-state coefficient of variation). Correspondingly, the 1990s saw steadily declining aggregate unemployment alongside a convergence of state unemployment rates. The only period during which aggregate unemployment was out of synch with the coefficient of variation was in 1986-87, when a handful of states had sudden increases in unemployment following the crash of energy prices in $1986 .{ }^{2}$ Along with the country as a whole, all other states saw falling unemployment during this period.

\footnotetext{
2 These states were Alaska, Alabama, Colorado, Louisiana, Mississippi, Texas, and Wyoming.
} 


\section{Figure 2}

\section{Changes in State Unemployment Rates Around Recessions}
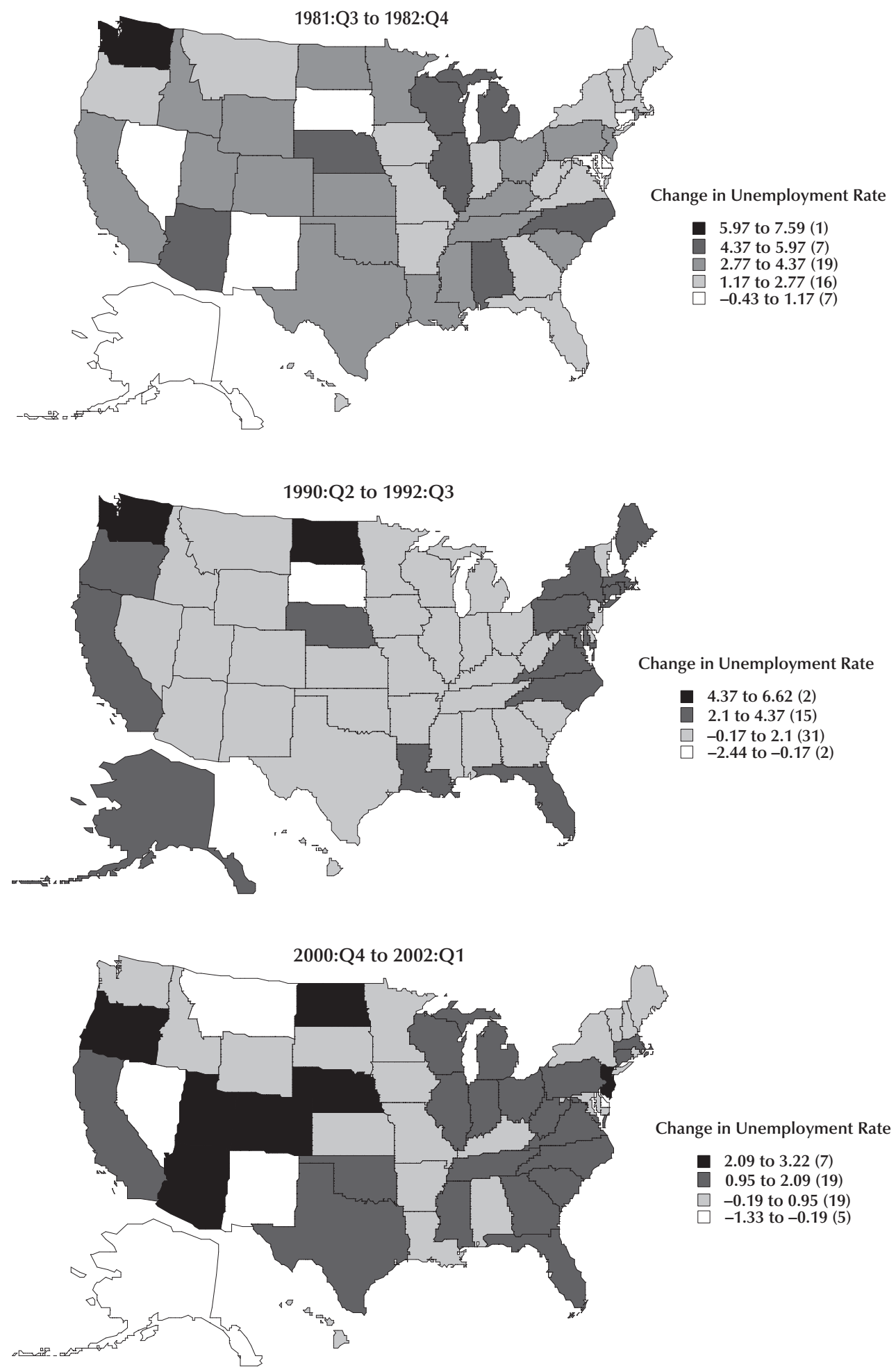
Figure 2 provides more evidence of the potential importance of regional labor market variation by showing the distribution of changes in state unemployment surrounding the three most recent recession episodes. ${ }^{3}$ Associated with the 1981-82 recession, the U.S. unemployment rate rose by about 3.3 percentage points from the third quarter of 1981 to the fourth quarter of 1982. Over the same period, 29 states saw smaller increases in their unemployment rates, 14 of which saw increases that were less than half as large (Nevada actually saw a small decrease). On the other hand, of the 21 states whose unemployment rates rose relatively more than the national average, 6 states saw a rise of at least 4.8 percentage points.

The period surrounding the 1990-91 recession is perhaps the most regionally distinct of the three most recent recessions. The aggregate unemployment rate rose by 2.3 percentage points from the second quarter of 1990 to the third quarter of 1992. The brunt of the increase was felt on the coasts, where most states saw increases in their unemployment rates that were much larger than averageparticularly the large states of California, New York, North Carolina, and Washington. In contrast, a significant majority of states (36), mostly located in the vast middle of the country, saw a milder than average increase in unemployment. In fact, four states actually saw their unemployment rates fall during the period.

Associated with the 2001 recession was a run-up in unemployment that began in the fourth quarter of 2000 and continued well after the end of the recession. By the first quarter of 2002, the fact of a regionally diverse unemployment experience, and an increasing coefficient of variation, had become clear. By that time, the aggregate unemployment rate had risen by 1.6 percentage points, although 35 states saw smaller increases than this, and 6 saw declines. The states hit most severely were scattered across the country, with pockets in the Great Lakes region, the Atlantic seaboard, the western Plains, and the Southwest.

\section{HOW REGIONAL BUSINESS CYCLES MIGHT MATTER}

Here, we describe how a nonlinear relationship between inflation and measures of labor market

\footnotetext{
3 As determined by the NBER, the dates for these recessions are July 1981 through November 1982, July 1990 through March 1991, and March 2001 through November 2001
}

pressures - such as vacancies, unemployment, and employment growth - would mean that differences in regional business cycles are able to affect measures of aggregate conditions. Such nonlinearities are standard in the theory of unemployment, and it is not difficult to find empirical evidence backing them up.

Numerous statistical studies of the distribution of wage changes point to a potential role for asymmetric wage adjustments and heterogeneity (see, for example, McLaughlin, 1999; and Card and Hyslop, 1997). These studies show that the distribution of wage changes is skewed away from small increases and absolute cuts and toward large increases. There is a thinning of the left-hand tail to the left of the zero-inflation point, thereby indicating nominal wage rigidity. As McLaughlin (1999) documents, the skewness of the distribution exists even in the absence of any nominal wage rigidity: Even if the distribution is truncated at zero wage increases, the distribution is still skewed. According to survey results from Truman Bewley (1999), managers are hesitant to cut wages because of considerations about worker morale. Wage cuts are likely to introduce personnel and incentive problems beyond the intended effect on turnover. It follows that in an economy where some sectors and/or regions are declining and others are expanding, the relative wage cuts occurring in the former are smaller than the wage increases offered in the latter.

This microeconomic evidence suggests that regional labor market disaggregation may have a role in illuminating aggregate labor market outcomes. This can be illustrated most simply with the textbook version of the Phillips curve that traces its origins to Phelps (1968). In this model, wage inflation persists because firms cannot adjust instantaneously to changes in vacancies. This might be due to the costs of setting wages or because wage setting is staggered over time. Thus, for a given unemployment rate, the rate of wage inflation is an increasing function of the number of vacancies that firms would like to fill and of inflation expectations. There is a critical vacancy rate, $\bar{v}$, at which actual wage inflation equals expected wage inflation. When the vacancy rate is above $\bar{v}$, there is unexpected wage inflation. Conversely, when the vacancy rate is below $\bar{v}$, there is unexpected wage deflation.

The microeconometric evidence we cite above suggests that the slope of the relationship between wage inflation and the vacancy rate differs above and below $\bar{v}$. This is because firms are more reluctant 
to cut expected wages than to raise them. So, starting from $\bar{v}$, a decrease in the vacancy rate will lead to wage deflation that is smaller in absolute terms than the wage inflation that would follow an equivalent increase in the vacancy rate. In other words, the relationship between wage inflation and the vacancy rate is convex because it is flatter for vacancy rates below $\bar{v}$.

To see how this convexity matters, consider an economy with two equal-sized regions, both with vacancy rates of $\bar{v}$. Now consider equal but oppositesigned changes in the regions' vacancy rates (i.e., the changes are mean-preserving). One region experiences unexpected wage inflation that is greater in absolute terms than the unexpected wage deflation in the other. Thus, a mean-preserving increase in the dispersion of regional vacancy rates is associated with higher average wage inflation. More generally, with a strictly convex relationship between wage inflation and the vacancy rate, the larger is the dispersion of regional vacancy rates, the higher is the aggregate wage inflation for any given aggregate vacancy rate.

\section{CONVEXITY AND THE NATURAL RATE IN THE UNITED STATES}

The discussion above describes how aggregate wage inflation can be affected by the dispersion of regional labor market conditions when the regionlevel relationship between wage inflation and labor market conditions is convex. To test for this convexity, we use state unemployment rates and rates of growth of employment as our measures of state labor market conditions. Unfortunately, there are no state-level data for vacancies. This gives rise to the following equation, which we estimate with state-level panel data:

$$
\begin{aligned}
\frac{\dot{w}_{i t}}{w_{i t}} & =\alpha_{0}^{i}+\alpha_{1} \frac{\dot{N}_{i t}}{N_{i t}}+\alpha_{1}\left(\frac{\dot{N}_{i t}}{N_{i t}}\right)^{2} \\
& +\alpha_{2} u_{i t}+\alpha_{2} u_{i t}^{2}+\alpha_{3} \frac{\dot{w}_{t}^{e}}{w_{t}}+\varepsilon_{i t}
\end{aligned}
$$

In (1), $i$ refers to the state, $t$ refers to the time period, $\dot{w}_{i t} / w_{i t}$ is wage inflation, $\alpha_{0}^{i}$ is a state fixed effect, $\dot{N}_{i t} / N_{i t}$ is employment growth, $u_{i t}$ is the unemployment rate, and $\dot{w}_{t}^{e} / w_{t}$ is expected aggregate wage inflation. We use quarterly data from 1977:Q3 to 2002:Q1. Our wage measure is hourly earnings in manufacturing, employment data are from the establishment survey, and the unemployment rate is from the household survey. Expected wage inflation at the aggregate level is measured by actual consumer price inflation (CPI) lagged one quarter. We estimate (1) with feasible generalized least squares (FGLS) to correct for state-specific autocorrelation and heteroskedasticity that is correlated across states. $^{4}$

As reported in Table 1 and illustrated by Figures 3 and 4, the coefficients for employment growth and the unemployment rate (in levels and squared) imply a convex relationship between wage inflation and regional labor market conditions. However, the coefficient on the squared employment term is not statistically significant at traditional levels, so the relationship is not statistically different from linearity. On the other hand, the convexity of the relationship between wage inflation and the unemployment rate is statistically significant.

The weight of this empirical evidence indicates that the relationship between labor market conditions and wage inflation is convex, meaning that changes in the dispersion of conditions across states will have repercussions at the aggregate level. In particular, divergent regional business cycles cause measured wage inflation to rise for a given aggregate unemployment rate. In other words, the aggregate unemployment rate at which wage inflation is unchanged will be higher. These results suggest one possible reason for the non-inflationary boom that took place in the United States in the 1990s. Recall Figure 1, which shows that the coefficient of variation of state unemployment rates fell throughout the period, indicating a convergence of economic activity. Consistent with our discussion, this decreased dispersion was accompanied by a falling aggregate unemployment rate but no increase in wage inflation.

To explore this possibility further, we estimate a relatively simple Phillips curve for the United States, including features common to Phillips curve models 5 :

4 We are able to correct for this most-general form of heteroskedasticity because our time series is relatively long for a cross-state panel. A useful rule of thumb is that this is possible if there are twice as many time periods as cross-sectional units (Beck and Katz, 1995), which our panel just satisfies.

5 The variety of Phillips curve specifications is vast; Staiger, Stock, and Watson (2001) alone includes dozens of different Phillips curve specifications and estimates. As Phelps (1968) noted 35 years ago, and which is no less true today, "The numerous Phillips-curve studies of the past ten years have... [offered] countless independent variables in numerous combinations to explain wage movements. But it is difficult to choose among these econometric models, and rarely is there a clear rationale for the model used" (p. 678). 


\section{Figure 3}

Wage Inflation and Employment Growth

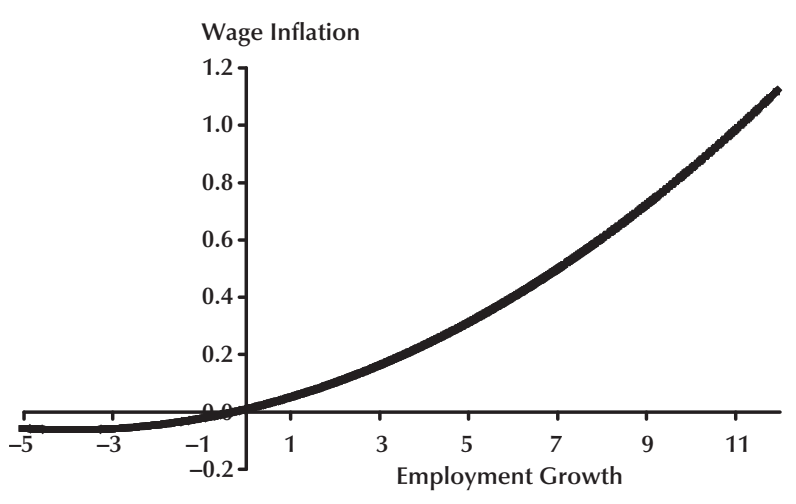

\section{Figure 4}

Wage Inflation and the Unemployment Rate

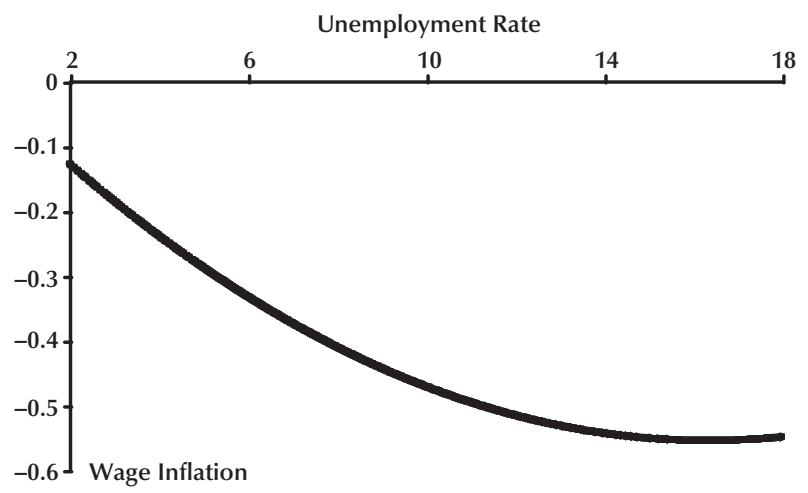

\section{Table 1}

\section{Wage Inflation and Vacancies in a State Panel}

\begin{tabular}{lccc} 
& Coefficient & Standard error & $t$ \\
\hline Employment growth & $0.0365^{*}$ & 0.0146 & 2.50 \\
Employment growth squared & 0.0047 & 0.0036 & 1.31 \\
Unemployment rate & $-0.0679^{*}$ & 0.0207 & 3.28 \\
Unemployment rate squared & $0.0021^{*}$ & 0.0012 & 1.66 \\
Expected wage inflation & $0.5907^{*}$ & 0.0293 & 20.14 \\
State fixed effects (48) & & Yes & \\
Observations & & 4,752 & \\
Estimated covariances & 1,176 & \\
Estimated autocorrelations & & 48 & \\
Log-likelihood & & $-4,587.42$ &
\end{tabular}

NOTE: * Indicates statistical significance at the 10 percent level. The estimator is FGLS and corrects for state-specific autocorrelation and heteroskedasticity with cross-state correlations. Quarterly state-level data, 1977:Q3-2002:Q1. Indiana and Kansas are excluded because of missing earnings data in early years of the sample. For space considerations, we do not report the estimates of the state fixed effects.

(2) $\frac{\dot{w}_{t}}{w_{t}}-\theta_{t}^{e}=\alpha_{0}-\alpha_{1} \ln u_{t}+\lambda X_{t}+\mathbf{B} \boldsymbol{\Phi}+\pi_{t}^{e}+\varepsilon_{t}$

In (2), the dependent variable is nominal hourly wage growth averaged over years $t$ and $t+1$ net of expected productivity growth, $\theta_{t}^{e}$, measured by the trend growth of output per worker in the nonfarm business sector. We also include a vector of demographic variables, $\boldsymbol{\Phi}$, to control for changes in the composition of the labor force (Phelps and Zoëga, 1997; Shimer, 1999; Francesconi et al., 2000; and
Staiger, Stock, and Watson, 2001). Following Staiger, Stock, and Watson (2001), these variables are the percentages of the adult population that are high school dropouts, college graduates, white, female, and aged 25-54. Expected wage inflation, $\pi_{t}^{e}$, is measured by average CPI inflation for years $t-1$ and $t-2$.

Our innovation is to include $X_{t}$, the coefficient of variation of state unemployment rates, which we expect to be positively related to wage inflation: Even if the aggregate unemployment rate is 


\section{Table 2}

\section{U.S. Phillips Curve Estimation}

\begin{tabular}{lcc} 
& $\begin{array}{c}\text { Coefficient of variation } \\
\text { and demographics }\end{array}$ & Demographics only \\
\hline Constant & $-112.326^{*}(57.196)$ & $-51.097(68.513)$ \\
Log unemployment rate & $-3.300^{*}(0.741)$ & $-3.036^{*}(0.958)$ \\
Coefficient of variation of state unemployment rates & $0.263^{*}(0.080)$ & - \\
High school dropouts & $0.957^{*}(0.542)$ & $1.098(0.817)$ \\
College graduates & $0.542^{*}(0.218)$ & $0.486^{*}(0.242)$ \\
White & $-0.044(1.057)$ & $-0.082(1.389)$ \\
Female & $1.645(1.751)$ & $0.798(2.561)$ \\
Aged 25-54 & $0.240^{*}(0.116)$ & $-0.005(0.119)$ \\
Expected wage inflation & $0.452^{*}(0.059)$ & $0.326^{*}(0.090)$ \\
\hline Observations & 19 & 19 \\
Log-likelihood & 7.781 & 1.566
\end{tabular}

NOTE: White-corrected standard errors are in parentheses. * Indicates significance at the 10 percent level. Yearly aggregate data, 1982-2000.

unchanged, an increase in the dispersion of labor market conditions will raise the aggregate rate of wage inflation.

In choosing the time frame for estimating (2), we are hampered by the lack of state-level data before 1977 and demographic variables after 2000. In addition, to eliminate the estimation problems associated with the so-called monetarist experiment period, we include only 1982 and later. Despite these restrictions, we obtain the fairly reasonable results reported by Table 2 .

Results for our more general specificationwhich includes demographic variables and the coefficient of variation of state unemployment rates - indicate that the education and age variables have all been important in determining the rate of wage inflation. More importantly for our present purposes, the results are consistent with our hypothesis that the regional dispersion of economic activity can affect aggregate wage inflation: The coefficient on the coefficient of variation of state unemployment is positive and statistically significant.

Table 2 also reports the results when the aggregate Phillips curve is estimated under the restriction that the coefficient of variation of state unemployment does not matter statistically. From these results it is clear that this restriction is not supported. When the coefficient of variation is excluded, the coefficient on only one of the demographic variablesthe share of college graduates - is anywhere close to being statistically significant. In addition, the constant term becomes smaller and statistically insignificant, making it very difficult to use the results to calculate a natural rate of unemployment. In sum, as supported by a likelihood-ratio test rejecting the null hypothesis that the restriction does not have a statistically significant effect, the estimates with the coefficient of variation are preferred.

According to Ball and Mankiw (2002), the primary source of the changes in the natural rate of unemployment in the 1990s was the acceleration of productivity growth (see also Pissarides, 2000; and Hoon and Phelps, 1997). An additional factor was the changing composition of the labor force (Phelps and Zoëga, 1997; Shimer, 1999; and Francesconi et al., 2000). Our Phillips curve estimation indicates that the convergence of state labor market conditions also had a role. The extent of this role can be obtained by examining the natural rates of unemployment implied by our Phillips curve estimation. Specifically, solving equation (2) by assuming that expected wage inflation is equal to last year's wage inflation, it can be rewritten as 
The Falling U.S. Natural Rate, 1982-2000

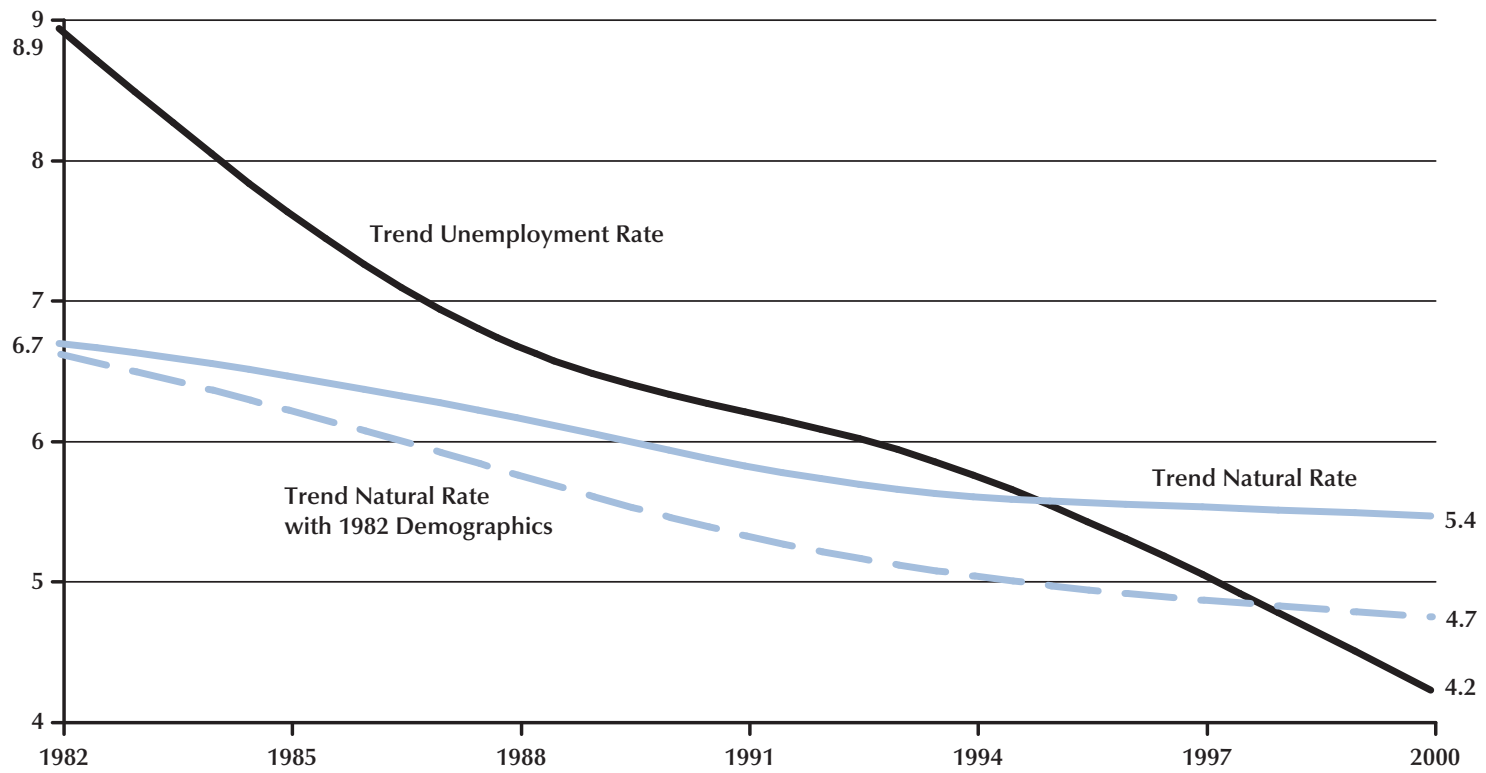

(3)

$$
\Delta\left(\frac{\dot{w}_{t}}{w_{t}}\right)=-\alpha_{1}\left(\log \left(u_{t}\right)-\log \left(u_{t}^{n}\right)\right)+\varepsilon_{i t},
$$

where $u_{t}^{n}=\exp \left[\left(\alpha_{0}+\lambda X+\mathbf{B} \boldsymbol{\Phi}\right) / \alpha_{1}\right]$ is the time-variant natural rate of unemployment. 6

The trend natural rate from our estimation and the actual trend unemployment rate are illustrated in Figure 5. According to our results, the natural rate fell steadily between 1982 and 2000, from 6.7 percent to 5.4 percent. Although relatively large, because the period's demographic changes worked to increase the natural rate, this 1.3-percentagepoint drop understates the importance of changes in the dispersion of state-level unemployment rates. To remove the effect of these changes, the dashed blue line in Figure 5 is what the trend natural rate of unemployment would have been if the demographic variables had remained fixed at their 1982 levels. ${ }^{7}$ As the figure indicates, if all else had remained constant, changes in the dispersion of state unem-

6 See Staiger, Stock, and Watson (1997) for an analysis of the precision of natural rate estimates.

7 Note that because our dependent variable in (2) is wage inflation net of productivity growth, the trend natural rates shown in Figure 5 are also net of the effect of productivity changes. ployment rates would have lowered the trend natural rate to 4.7 percent by 2000 .

\section{CONCLUSIONS}

Using state-level data, we find that there is a convex relationship between unexpected wage inflation and labor market conditions - as measured by the unemployment rate and employment growth. This convexity suggests that increases in the crossstate dispersion of unemployment rates and employment growth mean a higher level of aggregate wage inflation even if aggregate unemployment and employment growth are unchanged. Finally, we include the coefficient of variation of state unemployment rates in our estimation of an aggregate Phillips curve. From this, we find that the convergence of state labor market performance between 1982 and 2000 was responsible for a 2-percentage-point drop in the natural rate of aggregate unemployment.

\section{REFERENCES}

Abraham, Katharine G. and Katz, Lawrence F. "Cyclical Unemployment: Sectoral Shifts or Aggregate Disturbances?" Journal of Political Economy, June 1986, 94(3, Part 1), pp. 507-22. 
Ball, Laurence and Mankiw, N. Gregory. "The NAIRU in Theory and Practice." Journal of Economic Perspectives, Fall 2002, 16(4), pp. 115-36.

Beck, Nathaniel and Katz, Jonathan N. "What To Do (and Not To Do) with Time-Series Cross-Section Data." American Political Science Review, September 1995, 89(3), pp. 634-47.

Bewley, Truman F. Why Wages Don't Fall During a Recession. Cambridge, MA: Harvard University Press, 1999.

Brainard, S. Lael and Cutler, David M. "Sectoral Shifts and Cyclical Unemployment Reconsidered.” Quarterly Journal of Economics, February 1993, 108(1), pp. 219-43.

Card, David and Hyslop, Dean. "Does Inflation 'Grease the Wheels of the Labor Market'?" in Christina D. Romer and David H. Romer, eds., Reducing Inflation: Motivation and Strategy. Chicago: University of Chicago Press, 1997.

Carlino, Gerald and DeFina, Robert. "The Differential Regional Effects of Monetary Policy." Review of Economics and Statistics, November 1998, 80(4), pp. 572-87.

Carlino, Gerald and Sill, Keith. "Regional Income Fluctuations: Common Trends and Common Cycles." Review of Economics and Statistics, August 2001, 83(3), pp. 446-56.

Crone, Theodore M. "Using State Indexes to Define Economic Regions in the US." Journal of Economic and Social Measurement, 1998/1999, 25(3/4), pp. 259-75.

Francesconi, Marco; Orszag, J. Michael; Phelps, Edmund S. and Zoëga, Gylfi. "Education and the Natural Rate of Unemployment." Oxford Economic Papers, January 2000, 52(1), pp. 204-23.

Fratantoni, Michael and Schuh, Scott. "Monetary Policy, Housing, and Heterogeneous Regional Markets.” Journal of Money, Credit, and Banking, August 2003, 35(4), pp. 557-89.

Hoon, Hian Teck and Phelps, Edmund S. "Growth, Wealth and the Natural Rate: Is Europe's Jobs Crisis a Growth Crisis?" European Economic Review, April 1997, 41(3-5), pp. 549-57.

Layard, Richard; Nickell, Stephen and Jackman, Richard. Unemployment. Oxford: Oxford University Press, 1991.
Lilien, David M. "Sectoral Shifts and Cyclical Unemployment." Journal of Political Economy, August 1982, 90(4), pp. 777-93.

McLaughlin, Kenneth J. "Are Nominal Wage Changes Skewed Away From Wage Cuts?” Federal Reserve Bank of St. Louis Review, May/June 1999, 81(3), pp. 117-32.

Owyang, Michael T.; Piger, Jeremy and Wall, Howard J. “Business Cycle Phases in U.S. States.” Working Paper 2003-011, Federal Reserve Bank of St. Louis, October 2003.

Owyang, Michael T. and Wall, Howard J. "Regional Disparities in the Transmission of Monetary Policy." Working Paper 2003-008, Federal Reserve Bank of St. Louis, April 2003.

Overman, Henry G. and Puga, Diego. "Unemployment Clusters Across Europe's Regions and Countries." Economic Policy, April 2002, 34, pp. 115-47.

Phelps, Edmund S. "Money-Wage Dynamics and LaborMarket Equilibrium." Journal of Political Economy, JulyAugust 1968, 76(4, Part 2), pp. 678-711.

Phelps, Edmund S. Structural Slumps. Cambridge, MA: Harvard University Press, 1994.

Phelps, Edmund S. and Zoëga, Gylfi. "The Rise and Downward Trend of the Natural Rate." American Economic Review, May 1997, 87(2), pp. 283-89.

Pissarides, Christopher A. Equilibrium Unemployment Theory. Cambridge, MA: MIT Press, 2000.

Shimer, Robert. "Why Is the U.S. Unemployment Rate So Much Lower?" in Benjamin S. Bernanke and Julio Rotemberg, eds., NBER Macroeconomics Annual 1998. Volume 13. Cambridge, MA: MIT Press, 1999, pp. 11-61.

Staiger, Douglas; Stock, James H. and Watson, Mark W. "How Precise Are Estimates of the Natural Rate of Unemployment?" in Christina D. Romer and David H. Romer, eds., Reducing Inflation: Motivation and Strategy. Chicago: University of Chicago Press, 1997.

Staiger, Douglas; Stock, James H. and Watson, Mark W. "Prices, Wages, and the U.S. NAIRU in the 1990s," in Alan B. Krueger and Robert M. Solow, eds., The Roaring Nineties: Can Full Employment Be Sustained? New York: Russell Sage Foundation, 2001, pp. 3-60. 
RE V I E W 